\title{
PENGARUH MEDIA COVERAGE TERHADAP UNDERPRICING INITIAL PUBLIC OFFERING (IPO) DI BURSA EFEK INDONESIA
}

\author{
Jingga Novebreza Islah ${ }^{1)}$, Fajri Adrianto ${ }^{2)}$ \\ Program Studi MagisterManajemen Fakultas Ekonomi Universitas Andalas \\ novebreza.jingga@gmail.com
}

\begin{abstract}
Companies need large sources of funds to maintain their existence. One of the ways to get these funds is by conducting an IPO. In the IPO process, there are phenomena of underpricing and overpricing, one of which is influenced by the role of the media. This study aims to determine the effect of media coverage on IPO underpricing, which is proxied by stock initial returns. The object of research is a company that conducted an IPO on the Indonesia Stock Exchange in the period 20122017. A total of 76 companies from various industries that experienced IPO underpricing obtained using purposive sampling method were the samples of this study. Hypothesis testing is done using multiple linear regression analysis. The results showed that the national online media had a negative and insignificant effect, while the international online media had a positive and insignificant effect on stock initial returns, so that media coverage had no effect on IPO underpricing.
\end{abstract}

Keywords: Media Coverage, National Online Media, International Online Media, and IPO Underpricing.

Abstrak : Perusahaan membutuhkan sumber dana yang besar untuk mempertahankan eksistensinya. Salah satu cara untuk mendapatkan dana tersebut adalah dengan melakukan IPO. Dalam proses IPO terdapat fenomena underpricing dan overpricing yang salah satunya dipengaruhi oleh peran media. Penelitian ini bertujuan untuk mengetahui pengaruh media coverage terhadap underpricing IPO yang diproxikan dengan initial return saham. Objek penelitian adalah perusahaan yang melakukan IPO di Bursa Efek Indonesia pada kurun 2012-2017. Sebanyak 76 perusahaan dari berbagai industri yang mengalami underpricing IPO yang diperoleh dengan menggunakan metode purposive sampling menjadi sampel penelitian ini. Pengujian hipotesis dilakukan dengan menggunakan analisis regresi linear berganda. Hasil penelitian menunjukkan bahwa media online nasional berpengaruh negative dan tidak signifikan sedangkan media online internasional berpengaruh positif dan tidak signifikan terhadap initialreturn saham sehingga media coverage tidak berpengaruh terhadap underpricing IPO.

KataKunci:Media Coverage, Media Online Nasional, Media Online , Internasiona , dan Under pricing IPO

\section{A. PENDAhuluan}

Perusahaan yang memulai penawaran saham perdananya dikenal dengan istilah penawaran umum perdana atau Initial Public Offering (IPO). IPO merupakan penawaran saham perdana yang di lakukan oleh perusahaan kepada publik melalui pasar modal (Gautama, Diayudha, \& Puspitasari, 2015). Untuk Indonesia, pelaksanaan IPO ini diatur oleh Otoritas Jasa Keuangan (OJK). Perusahaan yang melakukan IPO 
dengan kredibelitasnya akan menyampaikan sinyal kepada calon investor untuk menunjukkan bahwa perusahaan tersebut layak diinvestasikan. Dengan adanya IPO perusahaan dapat menunjukkan kondisi keuangan dan bisnisnya kepada investor sehingga perusahaan bisa mendapatkan modal dan menjalankan strategi untuk perusahaan dimasa akan datang. Terdapat dua fenomena yang terjadi pada harga saham setelah IPO yaitu underpricing dan overpricing. Fenomena underpricing merupakan kejadian dimana harga saham perusahaan melonjak pada hari pertama perdagangan di pasar sekunder. Sementara itu overpricing merupakan kejadian dimana harga saham menurun pada hari pertama pedagangan di pasar sekunder (Gabriela, 2013). Untuk mengetahui apakah sebuah perusahaan mengalami underpricing ataupun overpricing dapat diketahui melalui informasi-informasi dari perusahaan tersebut.

Aliran informasi merupakan faktor kunci dalam menetapkan harga saham. Harga saham didasarkan pada perkiraan kinerja masa depan dan ramalan yang optimal memerlukan informasi yang lengkap perusahaan, industri dan ekonomi secara keseluruhan. Untuk mengakses informasi keuangan suatu perusahaan, investor bisa mendapatkannya melalui beberapa sumber seperti laporan langsung dari perusahaan, website, provider database dan media. Untuk pasar modal yang sudah maju (developed market), investor bisa mendapatkan informasi dari beberapa sumber database yang tidak saja menyediakan data yang bersifat publik tapi juga private. Kondisi mungkin relatif berbeda untuk investor yang berasal dari pasar modal yang sedang berkembang (developing market). Media massa yang menyediakan informasi secara gratis akan menjadi salah satu sumber informasi utama bagi investor ketika ingin mengetahui informasi suatu emiten, termasuk perusahaan yang akan melakukan IPO. Kredibilitas media merupakan faktor penting yang mempengaruhi bagaimana investor menafsirkan bukti media sebagai bentuk bahan yang dapat dipercayai. Biasanya liputan media tidak dapat secara terang-terangan positif atau negatif artinya, media mungkin memiliki informasi yang bersifat netral atau tidak pasti dalam cakupan perusahaan IPO (Guldiken, Tupper, Nair, \& Yu, 2017).

Berbagai laporan dari lembaga kompeten, baik nasional maupun internasional, baik pemerintah maupun institusi nonpemerintah, menunjukkan bahwa indeks minat baca dan tingkat literasi masyarakat Indonesia masih sangat rendah dan memprihatikan. UNESCO (United Nations Educational Scientic and Cultural Organization) pernah merilis data yang menunjukkan bahwa indeks minat baca di Indonesia hanya 0,001. Itu artinya dari seribu orang, hanya ada satu yang memiliki minat baca. Oleh karena itu, minat baca yang rendah menyebabkan masyarakat kekurangan informasi sehingga diperlukan minat baca yang tinggi untuk mendapatkan informasi termasuk informasi dari media.

Informasi dari media merupakan satu dari sedikit sumber yang memberikan sinyal tentang perusahaan yang baru terdaftar dalam konteks IPO akan mempengaruhi reaksi investor terhadap keputusan yang akan diambil oleh investor. Peran media akan sama dengan analisis karena cenderung akan memberikan rekomendasi atau saran dengan menyampaikan informasi yang berhubungan dengan perusahaan. Baik analis maupun media ingin meliput perusahaan dimana ada permintaan untuk liputan semacam itu (wartawan ingin menulis tentang perusahaan yang 'layak diberitakan'). Untuk mengakses informasi para investor memerlukan biaya yang relatif mahal sehingga menjadi hambatan bagi para investor di negara-negara berkembang untuk berinvestasi. Dalam hal ini media mampu menyediakan informasi yang diperlukan oleh investor 
sehingga mampu mengurangi hambatan bagi para investor dalam mengakses informasi, maka dari itu media menjadi sangat penting di dunia pasar modal.

Menurut Tong (2013) pengaruh berita media terhadap reputasi organisasi mengacu pada reputasi media, yaitu keseluruhan evaluasi perusahaan yang disajikan di media. Selain itu reputasi media dapat mempengaruhi evaluasi para pemangku kepentingan terhadap organisasi sehingga reputasi media memiliki kaitan dengan liputan media. Salah satu media yang terkenal reputasinya didunia adalah media Bloomberg. Untuk memperoleh informasi yang lengkap suatu perusahaan diperlukannya akses ke terminal Bloomberg. Namum untuk mengakses terminal Bloomberg di butuhkan biaya yang cukup besar untuk berlangganan. Dengan besarnya biaya untuk mengaakses informasi dari terminal Bloomberg maka para investor dapat mengaakses informasi dari media massa terutama media online karena media online memiliki rubrik khusus mengenai bisnis dan ekonomi serta update informasi yang lebih cepat dibandingkan dengan media cetak. Selain itu media online lebih convenient dan memerlukan usaha yang relatif lebih mudah dalam mendapatkan informasi terbaru.

Liputan media sangat mempengaruhi kepercayaan investor dalam memilih perusahaan yang akan diinvestasikan baik itu informasi positif ataupun informasi negative sekalipun. Berdasarkan latar belakang yang telah dipaparkan diatas, maka penelitian ini akan mengkaji mengenai pengaruh media coverage terhadap underpricing initial public offering (IPO). Maka dari itu, penulis tertarik untuk mengetahui lebih lanjut mengenai hal tersebut dengan menjadikan perusahaan IPO yang terdaftar di BEI sebagai objek penelitian. Dari latar belakang masalah yang telah dijelaskan oleh peneliti, maka rumusan masalah dalam penelitian ini: (1)Bagaimana pengaruh media online nasional terhadap underpricing Initial Public Offering (IPO) di Bursa Efek Indonesia. (2) Bagaimana pengaruh media online internasional terhadap underpricing Initial Public Offering (IPO) di Bursa Efek Indonesia.

\section{B. KAJIAN PUSTAKA}

\section{Initial Public Offering (IPO)}

Perusahaan yang membutuhkan dana dapat melakukan penerbitan surat berharga seperti saham (stock), obligasi (bond), dan sekuritas lainnya. Surat berharga yang baru dijual berupa penawaran perdana ke publik (Initial Public Offering) atau tambahan surat berharga baru jika perusahaan sudah go publik. IPO adalah jenis penawaran umum di mana saham di perusahaan biasanya dijual kepada investor institusi yang pada gilirannya menjual ke masyarakat umum di bursa efek untuk pertama kalinya (Seng, Yang, \& Yang, 2017). Menurut UU No.8 Tahun 1995, penawaran umum (emisi/go public/initial public offering) adalah kegiatan penawaran efek yang dilakukan oleh emiten untuk menjual efek kepada masyarakat berdasarkan tatacara yang diatur dalam UU pasar modal dan peraturan pelaksananya. Perusahaan tersebut akan menerbitkan saham-saham pertama, namun juga bisa menerbitkan saham keduanya. Biasanya perusahaan akan merekrut seorang bankir investasi untuk menjamin penawaran tersebut dan seorang pengacara untuk membantu dalam menulis prospektus.

\section{Underpricing}

Fenomena underpricing merupakan kejadian dimana harga saham perusahaan melonjak pada hari pertama perdagangan di pasar sekunder. Fenomena ini tercermin dari lonjakan harga pada saat saham pertama kali diperdagangkan di pasar sekuritas. Ini berarti pergerakan harga adalah kasus yang ekstrim dan dapat diklasifikasikan sebagai 
abnormal yang dapat memberi keuntungan bagi investor dalam jangka pendek (Indriani \& Marlia, 2013). Underpricing sering dikaitkan dengan initial return yang akan diterima oleh investor atau pemegang saham. Initial return merupakan keuntungan yang diterima oleh investor yang berasal dari selisih antara harga perdana suatu saham dengan harga pada saat di pasar sekunder.

\section{Signaling Theory}

Dalamteoripensinyalanditekankanbahwapentingnyainformasi

dikeluarkanolehperusahaanterhadapkeputusaninvestasipihak akandatangbagikelangsunganhidupsuatuperusahaandanbagaimanapasaranefeknya.

Informasi yang lengkap, relevan, akuratdantepatwaktusangatdiperlukanoleh investor di pasar modal sebagaialatanalisisuntukmengambilkeputusaninvestasi.

MenurutJogiyanto (2003) informasi yang dipublikasikansebagaisuatupengumumanakanmemberikan signal bagi investor dalampengambilankeputusaninvestasi.

Jikapengumumantersebutmengandungnilaipositif, makadiharapkanpasarakanbereaksipadawaktupengumumantersebutditerimaolehpasar. Padawaktuinformasidiumumkandansemuapelakupasarsudahmenerimainformasitersebut, pelakupasarterlebihdahulumenginterpretasikandanmenganalisisi

Informasitersebutsebagai signal baik (good news) atau signal buruk (bad news).Jikapengumumaninformasitersebutsebagaisinyalbaikbagi investor, makaterjadiperubahandalam volume perdagangansaham.

\section{Media Coverage}

Menurut Lewis et al., dalam Strauss \& Meer, (2017) surat kabar, dan khususnya laporan keuangan dan laporan analis, diasumsikan membentuk citra publik dan legitimasi perusahaan, sehingga mempengaruhi keputusan perdagangan investor. Selain itu, mengingat bahwa sumber berita semacam itu menikmati tingkat kehandalan dan relevansi yang tinggi dikatakan bahwa mereka cenderung mempengaruhi perdagangan. Meski begitu, ada dua alasan mengapa investor profesional mengandalkan liputan media saat membuat keputusan investasi. Pertama, seperti yang Shiller dalam Strauss \& Meer, (2017) berpendapat, orang-orang dalam kelompok yang memiliki kepentingan bersama dan mengkonsumsi seperangkat informasi serupa (misalnya, media keuangan), cenderung berpikir dan bertindak dengan cara yang sama, mengikuti perilaku. Kedua, untuk mengantisipasi pendapat pasar yang berlaku, investor cenderung mengikuti opini pasar konsensus, yang diasumsikan tercermin dalam media keuangan.

Media massa memiliki kekuatan untuk menyebarkan informasi tentang perusahaan kepada khalayak luas; dengan demikian membangkitkan perhatian yang mungkin diberikan investor kepada perusahaan-perusahaan ini. Dari perspektif ekonomi umum, Shiller dalam (Strauss \& Meer, 2017) berpendapat bahwa media ditakdirkan untuk menarik perhatian investor dengan melaporkan saham yang telah mengalami perubahan harga yang parah. Hal ini menyebabkan fluktuasi harga lebih lanjut, yang pada gilirannya datang bersamaan dengan media, lebih lanjut cakupan bukti menunjukkan bahwa media memfasilitasi pembentukan pemahaman dan kesan investor tentang perusahaan IPO (Bhattacharya, Galpin, Ray, \& Yu, 2009). Paparan media 
memberikan informasi dan interpretasi mendalam kepada investor dan meningkatkan visibilitas perusahaan. Visibilitas perusahaan IPO dapat meningkatkan status dan pada gilirannya, membantu memperoleh legitimasi di mata investor (Guldiken et al., 2017).

\section{Reputasi Media}

Informasi organisasi yang dilaporkan di media memang mencerminkan reputasi media organisasi tersebut dengan menggambarkan kegiatan evaluasi oleh berbagai kelompok pemangku kepentingan, dan seterusnya dalam liputan berita. Dengan kata lain, reputasi media adalah "konsep kolektif yang menghubungkan perusahaan, pekerja media, pemangku kepentingan, sumber berita tentang perusahaan, dan pembaca berita" yang terbentuk melalui proses sosial yang kompleks (Murphy, 2010).

Reputasi media, yang menurut media adalah reputasi organisasi menggabungkan persepsi stakeholder yang berbeda mengenai organisasi tersebut. Organisasi berusaha untuk mempengaruhi liputan media mengenai informasi perusahaan karena media dapat "mencatat pengetahuan dan opini publik tentang perusahaan dan mempengaruhi pengetahuan dan opini publik tentang perusahaan". Artinya, reputasi media akan mempengaruhi pengetahuan dan opini publik terhadap sebuah organisasi (Tong, 2013). Secara khusus, reputasi media substantif "berfokus pada aktivitas dan sifat individu atau bisnis". Sifat deskriptif dari reputasi media substantif menunjukkan bahwa "liputan berita perusahaan yang terkait dengan topik reputasi tertentu (misalnya, tanggung jawab sosial, produk dan layanan, dan kinerja keuangan) harus sesuai dengan penilaian publik terhadap dimensi-dimensi tertentu".

\section{Kerangka Pemikiran Teoritis}

\section{Pengaruh Media Coverage terhadap Underpricing Initial Public Offering (IPO)}

Reputasi underwriter dan profitabilitas berpengaruh negatif dan tidak signifikan terhadap kinerja saham perusahaan yang melakukan IPO di BEI, underpricing berpengaruh positif dan tidak signifikan terhadap kinerja saham perusahaan yang melakukan IPO di BEI, dan financial leverage berpengaruh negatif dan signifikan terhadap kinerja saham perusahaan yang melakukan IPO di BEI (Amelia, 2020) sehingga dapa dilihat hubungan negatif antara liputan media dan tingkat pengembalian bahwa ada berita asli dalam liputan media. Berita buruk bergerak lebih lambat. Dengan demikian, ketika liputan media berisi berita asli, perusahaan dengan berita positif mungkin melihat harga saham mereka naik dengan cepat, sementara perusahaan dengan berita negatif mungkin melihat dampak negatif selama beberapa bulan ke depan sehingga berpotensi menimbulkan hubungan negatif antara liputan media satu bulan dan tingkat pengembalian saham bulan berikutnya atau lebih.

Liputan media dapat menarik sentimen investor menghasilkan kenaikan jangka pendek dan pembalikan harga saham di kemudian hari (Liu, Sherman, \& Zhang, 2014). Hasil penelitian (Guldiken et al., 2017) menunjukkan bahwa cakupan media yang kredibel mengenai perusahaan IPO secara signifikan mempengaruhi harga sahamnya. Selain itu, temuan tersebut menunjukkan bahwa ketidakpastian dalam sifat liputan media tentang perusahaan IPO berpengaruh negatif terhadap harga sahamnya.

Cook et al. (2006) berpendapat bahwa initial return IPO berkorelasi positif dengan publisitas pra-penerbitan. (Liu, Sherman, \& Zhang, 2007) menemukan bahwa peran media dalam IPO berhubungan positif dengan underpricing. Selain itu, jumlah media merupakan sinyal bahwa perhatian media tinggi lebih positif daripada perhatian media yang rendah. Penelitian ini juga meneliti jumlah artikel berita. Engelberg dan 
Parsons (2011) menggunakan perbedaan liputan media lokal untuk mengidentifikasi dampak kausal liputan media tentang perdagangan investor. Menurut Jang semakin tinggi perhatian media, semakin rendah underpricing saham pada hari pertama perdagangan (Strauss \& Meer, 2017). Dari argumen diatas dapat dibuat hipotesis :

\section{H1 : Diduga Media Online Nasional berpengaruh negatif dan signifikan terhadap Underpricing IPO di BEI.}

Informasi dari media online internasional jauh lebih dipercaya oleh investor dikarenakan memiliki reputasi media yang baik. Menurut Tong (2013) pengaruh berita media terhadap reputasi organisasi mengacu pada reputasi media, yaitu keseluruhan evaluasi perusahaan yang disajikan di media. Selain itu reputasi media dapat mempengaruhi evaluasi para pemangku kepentingan terhadap organisasi sehingga reputasi media memiliki kaitan dengan liputan media. Dalam penelitian ini menggunakan Bloomberg sebagai media sehingga dapat diasumsikan semakin tinggi reputasi media maka semakin baik dilihat dari Bloomberg sebagai penyedia data terlengkap di dunia. Dari argument diatas dapat dibuat hipotesis :

\section{H2 : Diduga Media Online Internasional berpengaruh negatif dan signifikan terhadap Underpricing IPO di BEI}

\section{METODOLOGI PENELITIAN}

\section{Objek Penelitian}

Penelitian ini menggunakan pendekatan kuantitatif bersifat kausal. Populasi dalam penelitian ini adalah seluruh perusahaan yang melakukan IPO pada periode 2012-2017, sebanyak 128 perusahaan. Metode pemilihan sampel penelitian adalah non probability sampling dengan menggunakan teknik purposive sampling dimana kriteria dalam pemilihan sampel menggunakan perusahaan yang melakukan IPO di BEI periode 20122017 dan perusahaan yang mengalami underpricing. Berdasarkan kriteria tersebut, maka sampel penelitian berjumlah 76 perusahaan. Metode pengumpulan data yaitu metode observasi non partisipan didapatkan dari laporan keuangan perusahaan dan difilter dalam pencarian manual berita pada google.

Pertimbangan yang digunakan untuk memilih perusahaan yang dijadikan sampel adalah sebagai berikut :

1) Perusahaan yang melakukan IPO di BEI pada periode Januari 2012 sampai Oktober 2017.

2) Perusahaan yang mengalami underpricing.

3) Perusahaan yang IPO memiliki semua informasi yang dibutuhkan dalam penelitiannya diantaranya, tanggal listing, harga saham penawaran perdana, harga saham penutupan pertama di pasar sekunder, dan rasio-rasio yang dibutuhkan.

4) Kriteria untuk variabel media adalah media online yang sering disearch di google atau yang paling sering ditelusuri yang dapat dilihat melalui https://www.alexa.com/

\section{Pemilihan Sampel}

\begin{tabular}{|l|l|}
\hline Keterangan & Jumlah \\
\hline
\end{tabular}




\begin{tabular}{|l|c|}
\hline Perusahaan yang melakukan IPO tahun 2012-2017 & 128 \\
\hline Sampel dikeluarkan karna overpricing & 19 \\
\hline Data yang diperlukan tidak lengkap & 33 \\
\hline Jumlah & 76 \\
\hline
\end{tabular}

\section{Jenis dan Sumber Data}

Sumber data yang ddigunakan dalam penelitian ini adalah data sekunder dengan jenis penelitian kuantitatif. Pada penelitian ini data diperoleh dari prospektus perusahaan IPO yang tercatat dalam BEI untuk periode 2012-2017 (www.idx.co.id , ebursa.com).

\section{Prosedur Pengumpulan Data}

Data yang dikumpulkan dalam penelitian ini dengan menggunakan metode:

1. Metode Studi Pustaka, yaitu dengan melakukan telaah pustaka, eksplorasi dan mengkaji berbagai literatur pustaka seperti Jurnal, Buku dan Sumber-sumber lain yang berkaitan dengan penelitian.

2. Metode Dokumentasi, yaitu dengan cara mengumpulkan, mencatat, dan mengkaji data sekunder yang berupa laporan keuangan perusahaan yang terdaftar di BEI periode tahun2012-2017 .

\section{Variabel Penelitian}

Variabel penelitian adalah objek penelitian, atau apa yang menjadi titik perhatian suatu penelitian. Variabel yang dipakai dalam penelitian ini ada tiga jenis variabel, yaitu:

1. Variabel Dependen (Y)

Variabel dependen ialah variabel yang dapat dipengaruhi oleh variabel independen. Variabel dependen underpricing IPO diukur dengan initial return saham yaitu selisih harga penutupan hari pertama saham diperdagangan di pasar sekunder dengan harga penawarannya dibagi dengan harga penawaran. Mengukur initial return dengan rumus (Indriani \& Marlia, 2013) :

$$
I R=\frac{\text { harga penutupan }- \text { harga IPO }}{\text { harga IPO }}
$$

2. Variabel Independen (X)

Variabel independen adalah tipe variabel yang menjelaskan atau mempengaruhi variabel lain. Yang menjadi variabel independen dalam penelitian ini adalah :

a. Media Online Nasional

Variabel media online nasional diukur dengan menggunakan jumlah dari berita media online nasional mengenai perusahaan IPO di BEI. Jumlah berita ini didapatkan secara manual melalui pencarian pada google di internet. Media online nasional yang digunakan adalah Tempo, Kompas, Kontan, Detik, Bisnis, Viva, Okezone, Tribunnews, dan Liputan6. Media ini dipilih berdasarkan dari web www.alexa.com.

b. Media Online Internasional 
Variabel media online nasional diukur dengan menggunakan jumlah dari berita media online internasional mengenai perusahaan IPO di BEI. Jumlah berita ini didapatkan secara manual melalui pencarian pada google di internet. Media online internasional yang digunakan adalah Bloomberg dan CNBC. Media ini dipilih berdasarkan dari website www.alexa.com.

\section{Variabel Kontrol}

Variabel kontrol adalah variabel yang dapat dikendalikan sehingga pengaruh variabel independen terhadap dependen tidak dipengaruhi oleh faktor luar yang tidak diteliti. Yang menjadi variabel kontrol dalam penelitian ini :

a. Reputasi Underwriter

Reputasi underwriter dilihat dengan menggunakan rangking terbaik underwriter yang dilihat dari www.idx.com per masing-masing tahunnya.

b. Utang

Utang diukur dengan menggunakan log utang yang didapatkan dari utang perusahaan yang dijadikan ke dalam bentuk logatrima. Utang ini diperoleh berdasarkan laporan keuangan perusahaan ketika perusahaan IPO.

c. Financial Leverage

Kemampuan perusahaan didalam membayar hutang denga equity yang dimiliki merupakan financial leverage. Variabel ini diukur dengan Debt to Equity Ratio (DER) adalah perbandingan anatara total debt (total hutang) dengan total equity (total modal). Rumus DER :

$$
D E R=\frac{T O T A L H U T A N G}{E Q U I T Y}
$$

\section{HASIL DAN PEMBAHASAN}

\section{AnalisiStatistikDeskriptif}

Tabel 1. Statistik Deskriptif

\begin{tabular}{|c|c|c|c|c|c|}
\hline Variable & Obs & Mean & Std. Dev. & Min & Max \\
\hline IR & 76 & 0,3185658 & 0,2478605 & 0,011 & 0,7 \\
\hline JMON & 76 & 11,19737 & 8,419057 & 0 & 33 \\
\hline JMOI & 76 & 0,6710526 & 0,9293461 & 0 & 5 \\
\hline \hline RTU & 76 & 16,10526 & 14,8437 & 1 & 99 \\
\hline LU & 76 & 11,63237 & 0,7278807 & 9,06 & 13,33 \\
\hline DER & 76 & 2,222039 & 2,084874 & 0,03 & 8,955 \\
\hline
\end{tabular}

Sumber : Hasil Pengolahan Data Stata 12

Dilihat dari seluruh variabel yang memiliki nilai minimum terkecil adalah initial return (IR) sebesar 0,011 dan nilai maximum terbesar ada pada variabel rangking terbaik underwriter (RTU) yaitu sebesar 99 sedangkan nilai mean terkecil terdapat pada variabel initial return (IR) sebesar 0,3185658 dan nilai mean terbesar terdapat pada variabel rangking terbaik underwriter (RTU) sebesar 16,10526. Nilai standar deviasi terbesar juga dimiliki oleh variabel rangking terbaik underwriter (RTU) sebesar 
14,8437 sedangkan variabel yang memiliki nilai standar deviasi terkecil adalah initial return (IR) sebesar 0,2478605 .

\section{AnalisisRegresiLinear Berganda}

Metode analisis yang dilakukan dalam penelitian ini adalah analisis regresi berganda (multiple regression analysis). Analisis regresi dilakukan untuk menarik kesimpulan mengenai hubungan antar variabel bebas dan terikat. Sebelum melakukan uji regresi ini, telah terlebih dahulu dilakukan uji asumsi klasik agar menghasilkan model regresi yang baik. Semua variabel telah terdistribusi normal dan tidak ada gejala autokorelasi, multikolonearitas, maupun gejala heterokedasitas.

Tabel 2. Ouput Coefficients Initial Return Saham

\begin{tabular}{|c|c|c|c|c|}
\hline IR & Coef. & Std. Err. & $\mathbf{t}$ & P>t \\
\hline JMON & $-0,0027829$ & 0,0034088 & $-0,82$ & 0,417 \\
\hline JMOI & 0,051774 & 0,0308804 & 1,68 & 0,098 \\
\hline Konstanta & 0,3149841 & 0,0495598 & 6,36 & 0,000 \\
\hline
\end{tabular}

Sumber : Hasil Pengolahan dengan STATA 12

Data diatas menunjukkan hasil regresi linear berganda yang menghasilkan nilai koefisien masing-masing variabel independen (X) serta besarnya nilai konstanta. Dari data diatas maka didapatkan model regresi sebagai berikut :

Persamaan :

$\mathrm{IR}=0,3149841-0,0027829 \mathrm{JMON}+0,051774 \mathrm{JMOI}+\mathrm{e}$

Pada persamaan di atas diketahui nilai konstanta sebesar 0,3149841 yang berarti apabila semua variabel bernilai 0 , maka $I R$ akan bernilai 0,3149841 . Variabel JMON bernilai negatif yang artinya setiap kenaikan $1 \%$ JMON akan menurunkan $I R$ sebesar $0,0027829 \%$ dengan asumsi variabel lain konstan. Variabel JMOI bernilai positif yang artinya setiap kenaikan 1\% JMOI akan menaikkan IR sebesar 0,051774\% dengan asumsi variabel lain konstan.

Tabel 3. Ouput Coefficients Initial Return Saham menggunakan Variabel Kontrol

\begin{tabular}{|c|c|c|c|c|}
\hline IR & Coef. & Std. Err. & T & P>t \\
\hline JMON & $-0,0006176$ & 0,0028055 & $-0,22$ & 0,826 \\
\hline JMOI & 0,0469198 & 0,0251693 & 1,86 & 0,066 \\
\hline RTU & 0,0070324 & 0.0016728 & 4.20 & 0,000 \\
\hline LU & $-0,1111512$ & 0,0351287 & $-3,16$ & 0,002 \\
\hline DER & 0,0282771 & 0,0116383 & 2,43 & 0,018 \\
\hline Konstanta & 1,410855 & 0,4142303 & 3,41 & 0,001 \\
\hline
\end{tabular}

Sumber : Hasil Pengolahan STATA 12

Data tabel 3. diatas menunjukkan hasil regresi linear berganda yang menghasilkan nilai koefisien masing-masing variabel independen $(\mathrm{X})$ serta besarnya nilai konstanta. Dari data diatas maka didapatkan model regresi sebagai berikut : 
Persamaan :

$$
\begin{aligned}
\mathrm{IR}= & 1,410855-0,0006176 \mathrm{JMON}+0,0469198 \mathrm{JMOI}+0,0070324 \mathrm{RTU}-0,1111512 \mathrm{LU} \\
& +0,0282771 \mathrm{DER}+\mathrm{e}
\end{aligned}
$$

Pada persamaan di atas diketahui nilai konstanta sebesar 1,410855 yang berarti apabila semua variabel bernilai 0, maka IR akan bernilai 1,410855. Variabel JMNO bernilai negatif artinya kenaikan 1\% JMNO akan menurunkan IR sebesar 0,0006176\% dengan asumsi variabel lain konstan. Variabel JMIO bernilai positif yang artinya setiap kenaikan 1\% JMIO akan menaikkan IR sebesar 0,0469198 \% dengan asumsi variabel lain konstan. Variabel RTU bernilai positif artinya kenaikan 1\% RTU akan menaikkan IR sebesar 0,0070324\% dengan asumsi variabel lain konstan. Variabel LU juga bernilai negatif yang artinya setiap kenaikan $1 \%$ LU akan menurunkan IR sebesar $0,1111512 \%$ dengan asumsi variabel lain konstan. Dan terakhir variabel DER juga bernilai positif yang artinya setiap kenaikan 1\% DER akan menaikkan IR sebesar 0,0282771\% dengan asumsi bahwa variabel lain konstan.

Keterangan:

$\begin{array}{ll}\text { IR } & =\text { Initial Return } \\ \text { JMON } & =\text { Jumlah Media Online Nasional } \\ \text { JMOI } & =\text { Jumlah Media Online Internasional } \\ \text { RTU } & =\text { Rangking Terbaik Underwriter } \\ \text { LU } & =\text { Utang Perusahaan } \\ \text { DER } & =\text { Finansial Leverage } \\ \mathrm{e} & =\text { Koefisien error }\end{array}$

\section{PengujianHipotesis}

\section{UjiSimultan}

Untuk menunjukkan pengaruh secara simultan dari variabel independen penelitian terhadap variabel dependen maka dilakukan uji Simultan atau Uji-F. Adapun hasil uji signifikansi simultan antara variabel independen terhadap variabel dependen adalah sebagai berikut :

Tabel 4. Uji Simultan

\begin{tabular}{|l|r|}
\hline Number of obs & 76 \\
\hline F( 2, 73) & 1,58 \\
\hline Prob > F & 0,2139 \\
\hline R-squared & 0,0414 \\
\hline Adj R-squared & 0,0151 \\
\hline Root MSE & 0,24598 \\
\hline
\end{tabular}

Sumber : Hasil Pengolahan Data Stata 12

Hasil dari uji $\mathrm{F}$ didapat nilai Prob > F sebesar 0,2139 yang artinya besar dari 0,05. Hal ini menunjukkan bahwa model regresi tidak dapat memprediksi InitialReturn Saham. Maka dapat disimpulkan bahwa variabel media online nasional (JMON) dan media online internasional (JMOI) secara bersama-sama tidak mempunyai pengaruh yang signifikan terhadap variabel dependen Initial Return Saham atau H1 tidak diterima. 
Tabel 5. Uji Simultan menggunakan Variabel Kontrol

\begin{tabular}{|l|r|}
\hline Number of obs & 76 \\
\hline F $(\mathbf{5}, \mathbf{7 0})$ & 9,29 \\
\hline Prob $>$ F & 0,0000 \\
\hline R-squared & 0,3988 \\
\hline Adj R-squared & 0,3558 \\
\hline Root MSE & 0,19893 \\
\hline
\end{tabular}

Sumber : Hasil Pengolahan Data Stata 12

Hasil dari uji F didapat nilai Prob > F sebesar 0,000 yang artinya kecil dari 0,05. Hal ini menunjukkan bahwa model regresi dapat digunakan untuk memprediksi InitialReturn saham. Maka dapat disimpulkan bahwa variabel media online nasional (JMON), media online internasional (JMOI) serta variabel kontrol yang terdiri atas rangking terbaik underwriter (RTU), log utang (LU), dan financial leverage (DER) secara bersama-sama mempunyai pengaruh yang signifikan terhadap variabel dependen Initial Return Saham atau H1 diterima.

\section{AnalisisUji t Parsial}

Pengujian hipotesis parsial atau uji $\mathrm{t}$ parsial bertujuan untuk mengetahui hubungan signifikansi dari tiap variabel independen terhadap variabel dependen dan untuk mengetahui lebih lanjut variabel independen yang memberikan pengaruh dan tingkat signifikansinya paling besar terhadap variabel dependen. Significance Level yang digunakan pada uji ini adalah sebesar $0,05(\alpha=5 \%)$ dengan degree of freedom $(\mathrm{df})=\mathrm{n}-\mathrm{k}$ dimana $\mathrm{n}$ merupakan jumlah data sampel yang digunakan dan $\mathrm{k}$ merupakan jumlah variabel.

Untuk menguji apakah jumlah berita media online nasional dan jumlah berita media online internasional memiliki pengaruh signifikan terhadap Initial Return saham, maka dilakukan pengujian hipotesis sebagai berikut

Tabel 6. Uji t Initial Return Saham

\begin{tabular}{|c|c|c|c|c|}
\hline IR & Coef. & Std. Err. & $\mathbf{t}$ & $\mathbf{P}>\mathbf{t}$ \\
\hline JMON & $-0,0027829$ & 0,0034088 & $-0,82$ & 0,417 \\
\hline JMOI & 0,051774 & 0,0308804 & 1,68 & 0,098 \\
\hline Konstanta & 0,3149841 & 0,0495598 & 6,36 & 0,000 \\
\hline
\end{tabular}

Hasil Pengolahan Data Stata 12

Dari data diatas dapat dijelaskan bahwa variabel JMON dengan nilai koefisien negatif sebesar 0,0027829 tidak berpengaruh signifikan terhadap $I R$ karena $\mathrm{P}>\mathrm{t}$ sebesar 0,417 lebih besar dari 0,05 sehingga Ha ditolak, sedangkan JMOIdengan nilai koefisien 0,051774 tidak berpengaruh signifikan terhadap IR karena nilai $\mathrm{P}>\mathrm{t}$ sebesar 0,098 lebih besar dari 0.05 sehingga Ha ditolak. 
Tabel 7. Uji t Parsial menggunakan Variabel Kontrol

\begin{tabular}{|c|c|c|c|c|}
\hline IR & Coef. & Std. Err. & $\mathbf{T}$ & $\mathbf{P}>\mathbf{t}$ \\
\hline JMON & $-0,0006176$ & 0,0028055 & $-0,22$ & 0,826 \\
\hline JMOI & 0,0469198 & 0,0251693 & 1,86 & 0,066 \\
\hline RTU & 0,0070324 & 0.0016728 & 4.20 & 0,000 \\
\hline LU & $-0,1111512$ & 0,0351287 & $-3,16$ & 0,002 \\
\hline DER & 0,0282771 & 0,0116383 & 2,43 & 0,018 \\
\hline Konstanta & 1,410855 & 0,4142303 & 3,41 & 0,001 \\
\hline
\end{tabular}

Sumber : Hasil Pengolahan Data Stata 12

Dari data diatas dapat dijelaskan bahwa variabel JMONdengan nilai koefisien negatif sebesar 0,0006176 tidak berpengaruh signifikan terhadap $I R$ karena $\mathrm{P}>\mathrm{t}$ sebesar 0,826 lebih besar dari 0,05 sehingga Ha ditolak, sedangkan JMOIdengan nilai koefisien 0,0469198 tidak berpengaruh signifikan terhadap return saham karena nilai $\mathrm{P}>\mathrm{t}$ sebesar 0,066 lebih besar dari 0.05 sehingga Ha ditolak.

Rangking terbaik underwriter (RTU) dengan nilai koefisien positif sebesar 0,0070324 berpengaruh signifikan terhadap IR karena $\mathrm{P}>\mathrm{t}$ sebesar 0,000 kecil dari 0,05 sehingga Ha diterima, log utang(LU) dengan nilai koefisien negatif sebesar 0,1111512 berpengaruh signifikan terhadap IR karena $P>t$ sebesar 0,002 kecil dari 0,05 sehingga Ha diterima, sedangkan finansal leverage (DER) dengan nilai koefisien positif sebesar 0,0282771 berpengaruh secara signifikan terhadap IR karena $\mathrm{P}>\mathrm{t}$ sebesar 0,018 kecil dari 0,05 sehingga Ha diterima. Demikian dapat disimpulkan bahwa ketiga variabel kontrol dalam penelitian ini berpengaruh positif dan signifikan terhadap IR.

\section{AnalisisUjiKoefisienDeterminasi( R2)}

Koefisien determinasi atau $R$ square $\left(R^{2}\right)$ berfungsi untuk mengukur pengaruh variabel independen terhadap variabel dependen. Koefisien determinasi (R2) nilainya adalah antara 0 dan $1(0<\mathrm{R} 2<1)$, jika R2 mendekati 1 , maka terdapat hubungan yang kuat antara variabel bebas dan variabel terikat dan jika R2 mendekati 0, maka terdapat hubungan yang lemah antara variabel bebas dan variabel terikat.Besarnya nilai dari R2 dapat dilihat dari tabel berikut ini:

Tabel 8. Uji Determinasi Adj $\mathbf{R}^{2}$

\begin{tabular}{|l|r|}
\hline Number of obs & 76 \\
\hline F( 2, 73) & 1,58 \\
\hline Prob > F & 0,2139 \\
\hline R-squared & 0,0414 \\
\hline Adj R-squared & 0,0151 \\
\hline Root MSE & 0,24598 \\
\hline
\end{tabular}




\section{Sumber : Hasil Pengolahan Data Stata 12}

Adj $R$-squared sebesar 0,0151 hal ini menunjukkan bahwa terdapat hubungan yang sangat lemah antara variabel bebas dan variabel terikat, hal ini dibuktikan dengan determinasi R2 adalah $(0<0,0151<1)$ yang mendekati angka 0 . Dari hasil diatas maka disimpulkan bahwa variabel Media Online Nasionada (JMON) dan Media Online Internasional (JMOI) tidak mempengaruhi variabel terikat sebanyak 1,51\%, sedangkan sisanya sebesar $98,49 \%$ dipengaruhi oleh variabel lain.

Tabel 8. Uji Determinasi Adj $\mathbf{R}^{\mathbf{2}}$ dengan Variab
\begin{tabular}{|l|r|}
\hline Number of obs & 76 \\
\hline F( 5, 70) & 9,29 \\
\hline Prob > F & 0,0000 \\
\hline R-squared & 0,3988 \\
\hline Adj R-squared & 0,3558 \\
\hline Root MSE & 0,19893 \\
\hline
\end{tabular}

Sumber : Hasil Pengolahan Data Stata 12

Adj R-squared sebesar 0,3558 hal ini menunjukkan bahwa terdapat hubungan yang kuat antara variabel bebas dan variabel terikat, hal ini dibuktikan dengan determinasi R2 adalah $(0<0,3558<1)$ yang mendekati angka 1 . Dari hasil diatas maka disimpulkan bahwa variabel Media Online Nasionada (JMON) dan Media Online Internasional (JMOI) serta variabel kontrol terdiri atas Rangking Terbaik Underwriter (RTU), Log Utang (LU) dan Financial Leverage (DER) mempengaruhi variabel terikat sebanyak 35,58\%, sedangkan sisanya sebesar 64,42\% dipengaruhi oleh variabel lain yang tidak diteliti dalam penelitian ini.

\section{PengaruhMedia CoverageterhadapUnderpricing IPO}

Dalam pengaruh media online nasional hasil penelitian ini menunjukkan bahwa media online nasionalyang diukur dengan Jumlah Berita Media Online Nasional(JMON) mempunyai pengaruh negatif terhadap initialreturn saham. Ini ditunjukkan dari nilai koefisien regresi yang bernilai negatif sebesar 0,0027829, ini berarti setiap kenaikan satu pada JMONmaka secara relatif akan menurunkan sebesar 0,0027829 terhadap initial return saham. Dari uji signifikan yang telah dilakukan, jika $\mathrm{p}$ value $>0,05$ maka tidak signifikan. Namun jika $\mathrm{p}$ value $<0,05$ maka signifikan. Dari hasil uji signifikan JMONmenunjukkan nilai $\mathrm{p}$ value 0,417 dimana > 0,05 maka JMONtidak memiliki pengaruh yang signifikan terhadap initial return saham. Hal ini menyebabkan hipotesis yang menyatakan JMON berpengaruh negatif dan signifkan terhadap InitialReturn saham tidak dapat diterima. Ini berarti H1 ditolak.

Sedangkan hasil penelitian dengan menggunakan variabel kontrol yang terdiri dari RTU,LU dan DER menunjukkan bahwa media online nasional yang diukur dengan JMON mempunyai pengaruh negatif terhadap initial return saham. ini ditunjukkan dari nilai koefisien regresi yang bernilai negative sebesar 0,0006176, ini berarti setiap kenaikan satu pada JMONmaka secara relatif akan menurunkan sebesar 0,0006176 terhadap initial return saham. Dari hasil uji signifikan JMONmenunjukkan nilai $\mathrm{p}$ value 0,826 dimana > 0,05 maka JMONtidak memiliki pengaruh yang signifikan terhadap initial return saham. Hal ini menyebabkan hipotesis yang menyatakan JMON 
berpengaruh negatif dan signifkan terhadap InitialReturn saham tidak dapat diterima. Ini berarti $\mathrm{H} 1$ ditolak.

Dalam pengaruh media online internasional hasil penelitian ini menunjukkan bahwa media online internasionalyang diukur dengan Jumlah Berita Media Online Internasional(JMOI) mempunyai pengaruh positif terhadap initialreturn saham. Ini ditunjukkan dari nilai koefisien regresi yang bernilai negatif sebesar 0,051774, ini berarti setiap kenaikan satu pada JMOImaka secara relatif akan menaikkan sebesar 0,051774 terhadap initial return saham. Dari uji signifikan yang telah dilakukan, jika $\mathrm{p}$ value $>0,05$ maka tidak signifikan. Namun jika $p$ value $<0,05$ maka signifikan. Dari hasil uji signifikan JMOImenunjukkan nilai $\mathrm{p}$ value 0,098 dimana > 0,05 maka JMOItidak memiliki pengaruh yang signifikan terhadap initial return saham. Hal ini menyebabkan hipotesis yang menyatakan JMOI berpengaruh negatif dan signifkan terhadap InitialReturn saham tidak dapat diterima. Ini berarti $\mathrm{H} 2$ ditolak.

Sedangkan hasil penelitian dengan menggunakan variabel kontrol yang terdiri dari RTU,LU dan DER menunjukkan bahwa media online nasional yang diukur dengan JMOI mempunyai pengaruh negatif terhadap initial return saham. ini ditunjukkan dari nilai koefisien regresi yang bernilai negative sebesar 0,0469198, ini berarti setiap kenaikan satu pada JMOImaka secara relatif akan menurunkan sebesar 0,0469198 terhadap initial return saham. Dari hasil uji signifikan JMOImenunjukkan nilai p value 0,066 dimana > 0,05 maka JMOItidak memiliki pengaruh yang signifikan terhadap initial return saham. Hal ini menyebabkan hipotesis yang menyatakan JMOI berpengaruh negatif dan signifkan terhadap InitialReturn saham tidak dapat diterima. Ini berarti $\mathrm{H} 2$ ditolak.

Hasil penelitian ini sama dengan temuan Schulz \& Schöllin, (2006) bahwa media menunjukkan tidak ada efek pada harga saham, yang menyiratkan bahwa media massa gagal memanipulasi nilai stok yang akurat. Artinya, sejumlah besar liputan media tidak terkait dengan abnormal return yang lebih tinggi pada hari pertama perdagangan.Ini dikarenakan sulitnya melacak efek dari paparan media yang spesifik. Ketidaktahuan semua jenis media lainnya cenderung mendistorsi pengaruh potensial mengenai pergerakan harga dalam IPO. Dalam upaya untuk melacak efek media, sangat penting untuk mengetahui siapa penerima pesan media dan bagaimana komunikasi tersebut disampaikan. Selain itu penelitian konsisten menurut Liu, Sherman, \& Zhang, (2014) menemukan bahwa cakupan media pra-IPO berhubungan negatif dengan tingkat pengembalian yang diharapkan di masa depan, yang diukur dengan biaya modal tersirat.

Hasil penelitian tidak sesuai dengan penelitian teori Guldiken, Tupper, Nair, \& Yu, (2017) bahwa cakupan media yang kredibelitas mengenai perusahaan IPO secara signifikan mempengaruhi harga sahamnya. Selain itu, temuan tersebut menunjukkan bahwa ketidakpastian dalam sifat liputan media tentang perusahaan IPO berpengaruh negatif terhadap harga sahamnya. Temuan Pollock dan Rindova (2003) bahwa bersifat positif liputan media menunjukkan efek ambang pada harga perusahaan IPO, di luar bersifat positif yang mungkin terkait dengan underpricing yang meningkat. Underpricing mengacu pada fenomena di mana harga penutupan perusahaan IPO pada hari perdagangan pertama lebih tinggi dari harga penawaran awal.

\section{E. KESIMPULAN DAN SARAN}

\section{Kesimpulan}

Berdasarkan hasil penelitian dan pembahasan yang telah dikemukakan pada bab sebelumnya, maka hasil dari penelitian ini dapat disimpulkan sebagai berikut : 
Uji regresi dalam penelitian ini menunjukkan bahwa media coverage yang dibagi menjadi dua yaitu media online nasional dan media online internasional tidak berpengaruh terhadap underpricing IPO. Ini dapat dilihat secara simultan ataupun secara parsial bahwa variabel independen tidak mempunyai pengaruh atau signifikasi terhadap uderpricing IPO.

Akan tetapi ketika dimasukkan variabel kontrol ke dalam formula regresi terjadi ke signifikan pada uji simultannya. Sehingga secara simultan variabel indenpenden memiliki pengaruh terhadap variabel dependennya. Ini dikarenakan variabel kontrol yang terdiri dari Rangking Terbaik Underwriter, dan Financial Leverage yang mana secara parsial mempunyai pengaruh terhadap underpricing IPO. Sedangkan untuk variabel independen yaitu media online nasional dan media online internasional ketika menggunakan variabel kontrol juga tidak berpengaruh secara parsial terhadap underpricing IPO.

Dalam uji regresi yang telah dilakukan menunjukkn nilai koefisien untuk variabel independen media online nasional adalah negative, sedangkan untuk variabel media online internasional memiliki nilai koefisien positif serta signifikansi pada kedua media juga tidak ada. Selain itu juga dapat dilihat dari $\mathrm{R}^{2}$ bahwa kurang dari $5 \%$ pengaruh kedua media ini terhadap underpricing IPO. Namun, ketika menggunakan varibel kontrol dapat diketahui nilai $\mathrm{R}^{2}$ yang lebih dari $20 \%$. Sehigga dapat disimpulkan bahwa media coverage tidak memiliki pengaruh terhadap underpricing IPO akan tetapi dengan menggunakan variabel kontrol dapat memberikan pengaruh terhadap underpricing IPO.

\section{Saran}

\section{Penelitian Selanjutnya}

Dari pembahasan dan kesimpulan yang diperoleh maka penulis memberikan saran sebagai berikut :

1) Penelitian dapat memperpanjang periode data perusahaan yang akan dijadikan untuk penelitian.

2) Penelitian berikutnya dapat melihat variabel lainya yang lebih berpengaruh terhadap underpricing IPO seperti reputasi auditor, size perusahaan dan ROA ROE perusahaan.

3) Penelitian yang akan datang diharapkan untuk menambahkan liputan berita media pasca IPO untuk melihat rentang waktu yang lebih panjang untuk mendeteksi underpricing IPO.

4) Penelitian selanjutnya bisa mengelompokkan jenis perusahaan atau jenis industri pada perusahaan IPO.

\section{F. DAFTAR PUSTAKA}

Amelia, P. (2020). Jurnal Manajemen Strategi dan Simulasi Bisnis (JMASSBI) Vol 1 No. 1 2020. 1(1), 49-65.

Basuki, Agus Tri and Prawoto, Nano. 2016. Analisis Regresi Dalam Penelitian Ekonomi \& Bisnis : Dilengkapi Aplikasi SPSS \& EVIEWS. Depok : PT Rajagrafindo Persada.

Bhattacharya, U., Galpin, N., Ray, R., \& Yu, X. 2009. The role of the media in the internet IPO bubble. Journal of Financial and Quantitative Analysis, 44(3), 657- 
682.

Carey, P., Fang, V., \& Zhang, H. F. 2016. The role of optimistic news stories in IPO pricing. Journal of International Financial Markets, Institutions and Money, 41, $16-29$.

Engelberg J, Parsons C . 2011 The causal impact of media in financial markets. J. Finance 66(1):67-97

Gabriela, L. S. 2013. Analisa faktor-faktor yang mempengaruhi Initial Return setelah Initial Public Offering ( IPO ). FINESTA, 1(2), 67-72.

Gautama, A., Diayudha, L., \& Puspitasari, V. A. 2015. Analisa faktor-faktor yang mempengaruhi Initial Return setelah Initial Public Offering ( IPO ). Jurnal Administrasi Kantor, 3(2).

Guldiken, O., Tupper, C., Nair, A., \& Yu, H. 2017. The impact of media coverage on IPO stock performance. Journal of Business Research, 72, 24-32.

Ghozali, Imam.2011. Aplikasi analisis multivariate dengan program SPSS. Edisi V. Semarang: Universitas Diponegoro

Hadi, Nor. 2013. Pasar Modal: Acuan Teoretis dan Praktis Investasi di Instrumen Keuangan Pasar Modal. Edisi Pertama. Yogyakarta: Graha Ilmu

Indriani, S., \& Marlia, S. 2013. The evidence of IPO underpricing in Indonesia 2009 2013. Review of Integrative Business and Economics Research, 4(1), 299-316.

Jogiyanto, HM. 2003. Teori Portofolio dan Analisis Investasi, Edisi Kedua, Yogyakarta : BPFE

Kraus, K., \& Strömsten, T. 2012. Going public: The role of accounting and shareholder value in making sense of an IPO. Management Accounting Research, 23(3), 186201.

Latan, Hengky. 2014. Aplikasi Analisis Data Statistik Untuk Ilmu Sosial Sains dengan IBM SPSS. Bandung: Alfabeta

Liu, L. X., Sherman, A. E., \& Zhang, Y. 2007. Media coverage and IPO underpricing. AFA 2009 San Francisco Meetings Paper, 2007.

Liu, L. X., Sherman, A. E., \& Zhang, Y. 2008. The Role of the media in Initial Public Offerings *. SSRN Working Paper.

Liu, L. X., Sherman, A. E., \& Zhang, Y. 2014. The long-run role of the media: evidence from Initial Public Offerings. Management Science, 60(8), 1945-1964.

Martono, Nanang.2011. Metode Penelitian Kuantitatif: Analisis Isi dan Analisis Data Sekunder. Jakarta : Rajawali Pers.

Murphy, P. 2010. The intractability of reputation: Media coverage as a complex system in the case of Martha Stewart. Journal of Public Relations Research, 22(2), 209- 
Pollock, T., \& Rindova, V. 2003. Media legitimation effects in the market for initial public offerings. Academy of Management Journal, 46, 631-642.

Putra, I. P. E. P., \& Sudhjarni, L. K. 2017. Pengaruh reputasi underwriter, ukuran perusahaan, dan jenis industri terhadap underpricing Saat IPO di BEI. E-Jurnal Manajemen Unud, 6(1), 492-520.

Ragas, M., Kim, J., \& Kiousis, S. 2011. Agenda-building in the corporate sphere: Analyzing influence in the 2008 Yahoo!-Icahn proxy contest. Public Relations Review, 37(3), 257-265.

Schulz, F., \& Schöllin, L. 2006. The media coverage and its influence on the share price in an Initial Public Offering. Master Thesis.School of Ekonomic and Commersial Law.Goteborg University.

Sekaran, Uma. 2011. Metodologi Penelitian untuk Bisnis.Buku 1.Jakarta :Salemba

Seng, J., Yang, P., \& Yang, H. 2017. Initial public offering and financial news. Journal of Information and Telecommunication, 1(3).

Strauss, N., \& Meer, T. G. L. A. van der. 2017. News media coverage and initial public offerings in Germany: explaining flotation performance Initial, Corporate Communications, 22(4), 523-541.

Sugiyono. 2012. Metode penelitian kuantitatif kualitatif dan R\&D. Bandung : Alfabeta. Sukandarrumidi. 2012. Metodologi penelitian. Yogyakarta : Gadjah Mada University Press

Sunariyah. 2004. Pengantar Pengetahuan Pasar Modal; Edisi Keempat. Yogyakarta: UMP AMP YKPN

Suwardi, A. 2011. (Modul Stata) tahapan dan perintah (syntax) mengolah data panel.Computing laboratory of economics department. Universitas of Indonesia. Depok.

Tong, S. C. 2013. Media reputation in Initial Public Offerings: A study of financial news coverage in Hong Kong. Public Relations Review, 39(5), 470-483.

Wijaya, Tony. 2012. Cepat Menguasai SPSS 20 untuk olah dan Interpretasi Data. Yogyakarta :Cahaya Atama Pustaka. 2014 